\title{
PHYSICAL-CHEMICAL CHARACTERIZATION AND WET MILLING YIELD OF FOUR MAIZE HYBRIDS
}

\section{RENATA C. MUSSOLINI ${ }^{1}$, JOSÉ F. LOPES FILHO ${ }^{2}$, AILDSON P. DUARTE ${ }^{3}$}

\begin{abstract}
The influence of physical-chemical characteristics of maize grains and lactic acid concentrations on byproduct yields, generated by conventional wet milling, was studied during steeping, for four maize hybrids and two lactic acid concentrations ( 0.55 and $1.00 \%)$. For physicalchemical characterization, grain dimensions (length, thickness, and width) were determined, as well as mass of 100 grains, percentage of floating grains, volumetric mass, and centesimal composition. Statistical differences were found for percentage of floating grains (2.33 to $24.67 \%$ ), volumetric mass $\left(0.814\right.$ to $\left.0.850 \mathrm{~kg} . \mathrm{L}^{-1}\right)$, mass of 100 grains $(0.033$ to $0.037 \mathrm{~kg})$, water content (11.86 to $12.20 \%$ ), proteins (8.21 to $9.06 \%$ ), lipids (3.00 to $4.77 \%$ ), and ashes (1.07 to $1.26 \%$ ). There were no relationships of wet milling yields with maize appearance and physical-chemical characteristics. The addition of $1.00 \%$ lactic acid did not statistically improve byproduct yields; however, it favored separation of the grain components.
\end{abstract}

KEYWORDS: Zea mays L., physical-chemical properties, starch recovery, steeping.

\section{CARACTERIZAÇÃO FÍSICO-QUÍMICA E RENDIMENTO DA MOAGEM ÚMIDA DE QUATRO HÍBRIDOS DE MILHO}

RESUMO: Para verificar a influência da aparência e as características físico-químicas do grão de milho e da concentração de ácido lático durante a maceração nos rendimentos de subprodutos da moagem úmida convencional, quatro híbridos de milho foram caracterizados e macerados em duas concentrações de ácido lático (0,55\% e 1,00\%). Para a caracterização físico-química dos grãos, foram determinadas suas dimensões (comprimento, espessura e largura), massa de cem grãos, porcentagem de grãos boiantes, massa volumétrica e análise da composição centesimal. Diferenciaram-se estatisticamente entre os grãos a porcentagem de grãos boiantes $(2,33 \%$ a 24,67\%), massa volumétrica $\left(0,810 \mathrm{~kg} \mathrm{~L}^{-1}\right.$ a $\left.0,850 \mathrm{~kg} \mathrm{~L}^{-1}\right)$, massa de cem grãos $(0,033 \mathrm{~kg}$ a 0,037 kg), teor de água (11,86\% a 12,20\%), proteínas (8,21\% a 9,06\%), lipídeos (3,00\% a 4,77\%) e cinzas $(1,07 \%$ a $1,26 \%)$. Verificou-se que não há relação entre a aparência ou a composição química dos grãos com seus rendimentos de subprodutos na moagem úmida. A adição de 1,00\% de ácido lático não proporcionou, estatisticamente, melhores rendimentos de subprodutos, entretanto facilitou a separação dos componentes do grão.

PALAVRAS-CHAVE: Zea mays L., propriedades físico-químicas, recuperação de amido, maceração.

\section{INTRODUCTION}

The wet milling, which is the second largest maize consumer sector, is responsible for grain separation into its basic components (byproducts with higher added value): germ, fiber, protein (gluten), and starch (LOPES FILHO, 1999). This separation is possible due to the stage of grain steeping, which consists in their submersion into a solution containing lactic acid and sulfur dioxide

\footnotetext{
${ }^{1}$ Eng $^{\mathrm{a}}$ de Alimentos, Mestre, Depto. de Engenharia e Tecnologia de Alimentos, Universidade Estadual Paulista "Júlio de Mesquita Filho”, São José do Rio Preto-SP, Fone: (17) 3343-2677, renata@fornopaulista.com.br

2 Engo Alimentos, Prof. Dr, Depto. de Engenharia e Tecnologia de Alimentos, Universidade Estadual Paulista "Júlio de Mesquita Filho”, São José do Rio Preto-SP, lopes@ibilce.unesp.br

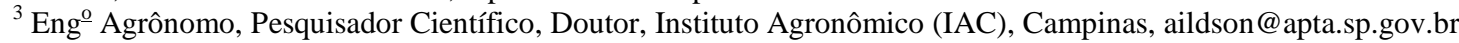

Recebido pelo Conselho Editorial em: 7-12-2010
}

Aprovado pelo Conselho Editorial em: 12-2-2014 
$\left(\mathrm{SO}_{2}\right)$. Transfer of the solution into the grains occurs during this stage and produces changes in physical, chemical, and biochemical properties. The presence of lactic acid in the steeping solution, besides softening the cell wall, generates favorable conditions for separation of the grain components (ROUSHDI et al., 1981). The $\mathrm{SO}_{2}$ penetrates the grains and is responsible for breaking the protein matrix in the endosperm by disrupting their disulfide bonds (S-S), releasing large starch amounts (ECKHOFF and TSO, 1991). To improve the maize wet milling process, the grain absorption mechanisms of water, $\mathrm{SO}_{2}$, and lactic acid during steeping must be understood (LOPES FILHO et al., 2006). Many studies have been performed to evaluate these mechanisms; however, the interest in the relationship between grain quality and a more appropriate use destination has also increased (FOX et al., 1992). There are not many studies on grain characterization and influence of its characteristics on byproduct yields. Moreover, the current classification standard does not allow estimates of values to allocate a grain for either wet milling or any other process. It is believed that grains with high starch content will provide better starch yields; however, other intrinsic factors, such as their chemical composition, may affect yield (FOX et al., 1992). The knowledge on the relationship among these factors may allow a rapid assessment of grain quality and improve the wet milling process, reducing losses. One example is that, although there are variations in the chemical composition of maize grains, the criteria used in Brazil for classification are based on grain physical and appearance characteristics. Grains with flint appearance (higher density) are preferred due to the fact that they are mistakenly believed to have higher hardness, breakage resistance, and solid contents. However, this evaluation is not appropriate to determine maize quality, resulting in the rejection of high yield potential cultivars for presenting grains of dent appearance or low volumetric mass (DUARTE et al., 2008). Thus, the objective of this study was to verify the influence of the appearance and physical-chemical composition of maize grains on byproduct yields from wet milling. It was also verified the influence of lactic acid concentrations in the steeping solution on the same byproducts.

\section{MATERIAL AND METHODS}

Samples of the following four maize hybrids, marketed in São Paulo State, Brazil, were used: 2B587 (dent kernel), Somma (flint kernel), and A2555 and 30F98 (intermediate appearance). The hybrids were obtained from experiments for cultivar evaluation belonging to IAC/APTA Maize Program, developed in 2006/2007 harvest, in both Cruzália and Pedrinhas Paulista municipalities, located in the Médio Paranapanema region, in Southwestern São Paulo State.

Grain size: Grain size was determined by measuring length (A), width (B), and thickness (C) of each grain, using a caliper of $0.02 \mathrm{~mm}$ resolution; 200 grains of one sample for each hybrid were evaluated. From means of each dimension, the prediction interval PI $=\mathrm{X} \pm \mathrm{SD}$ was determined, where $\mathrm{X}$ is the mean, and SD the standard deviation.

Mass of 100 grains: Mass of 100 grains was determined for each maize type, using an analytical scale, with three replications.

Analysis of floating grains: This analysis was performed according to the method described by PEPLINSK et al. (1989); grains were immersed into a sodium nitrate solution, with density adjusted to $1.271 \mathrm{~kg} \mathrm{~m}^{-3}$ and temperature ranging from 16 to $21^{\circ} \mathrm{C}$. Thus, the relationship between chalky endosperm (less dense floating grains) and hard endosperm (denser immersed grains) may be estimated.

Volumetric mass determination: Mass (in kilograms) of three 1-liter subsamples was determined for each grain type.

Grain centesimal composition: Determination of water content was performed in an oven, with no forced air circulation, according to the method described by the United States Department of Agriculture (USDA), which establishes time and temperature in the oven for different product types. For maize, this binomial is $103^{\circ} \mathrm{C}$ for 72 hours (HANAN et al., 1985). Protein determination was performed according to the method 46-12 of the American Association of Cereal Chemists 
(AACC, 1995), and the ashes, according to the method 08-01, by calcination in muffle furnace at $550{ }^{\circ} \mathrm{C}$. Lipids were determined according to Analytical Standards of IAL (1985), using Soxhlet extractor with petroleum ether as the solvent (method 4.10). Fiber determination was performed after digestion of the defatted sample with acid $\left(\mathrm{H}_{2} \mathrm{SO}_{4}\right)$ and basic $(\mathrm{NaOH})$ solutions, followed by filtration (MERTENS, 1992); the fiber corresponded to the final residue after filtration. Finally, determination of carbohydrates was calculated by the difference of percentages, i.e., the sum of the values obtained in the determination of the other components was subtracted from $100 \%$.

Grain wet milling: Grains were steeped in $3.0 \mathrm{~L}$ tanks for 36 hours under forced circulation of the steeping solution (300 $\mathrm{mL} \mathrm{s}^{-1}$ ), which consisted of $0.20 \% \mathrm{SO}_{2}$, and $0.55 \%$ or $1.00 \%$ acid lactic, at $48-52{ }^{\circ} \mathrm{C}$. After steeping, grains were ground in a blender (first milling). Due to the density difference, the germ, which is less dense, was recovered with the aid of small screens, mesh numbers 14 and 16, rinsed to remove aggregated starch and fibers, and then dried in an oven at $49^{\circ} \mathrm{C}$ for 12 hours. Separation time was maintained at around 50 minutes for standardization and comparison.

The degermed mass was sent to a disk mill for particle reduction and obtainment of a thin homogeneous paste, which remained at rest to allow solid decantation. The decanted solids and supernatant was sieved trough a 325-mesh vibrating screen to separate the fiber, which was dried at $49^{\circ} \mathrm{C}$ for 12 hours in an oven.

The starch-protein separation (solution that passed through the sieve) was performed on starch tables composed of U-shaped aluminum channels of approximately $0.08 \mathrm{~m}$ width, $6.0 \mathrm{~m}$ length, and $2^{\circ}$ inclination. These values were determined in studies (SINGH \& ECKHOFF, 1996) for better starch decantation and its minor protein contamination. For starch and protein separation, the solution density was adjusted to $0.104 \mathrm{~g} \mathrm{~mL}^{-1}$, which was measured with the aid of an aerometer. The solution, kept under agitation, was then pumped to the table at a speed of $30 \mathrm{~mL} \mathrm{~min}^{-1}$. Denser starch decanted into the channels, while the protein was collected in another container at the end of the channel. After 24 hours, the starch was removed from the channel with spatulas and brushes, and dried at $49^{\circ} \mathrm{C}$ for 12 hours in an oven. Protein recovery was performed by vacuum filtration; after that, the protein retained on the filter paper (which was previously weighed) was dried at $49^{\circ} \mathrm{C}$ for $12 \mathrm{~h}$.

The amounts of soluble solids present in the steeping and filtration solutions were also determined to complete mass balance. For this purpose, solution samples were placed in an air forced circulation oven at $49^{\circ} \mathrm{C}$ for 12 hours, and then placed in an oven at $103{ }^{\circ} \mathrm{C}$ for 5 hours. The remaining material was weighed to determine the amount of soluble solids for the entire solution volume. Moisture content of each grain fraction after drying was determined for yield calculation in relation to the initial maize dry matter. From the sum of fraction results and comparison with the initial sample dry matter, the total milling yield was calculated.

Experimental design: this study was conducted using a $4 \times 2$ factorial design corresponding to four maize hybrids and two concentrations of lactic acid. Means of physical (dimensions, mass of 100 grains, percentage of floating grains, and volumetric mass) and chemical (percentages of moisture, carbohydrate, protein, lipids, ashes, and fiber) characteristics were determined, as well as starch, protein, fiber, germ, and solid yields. These results were submitted to variance analysis and compared by Tukey test at $5 \%$ probability level, using ESTAT software (BANZATTO \& KRONKA, 1995).

\section{RESULTS AND DISCUSSION}

\section{Physical-chemical characterization}

Table 1 shows values of length (A), width (B), and thickness (C), and percentage of floating grains, volumetric mass, and mass of 100 grains. 
TABLE 1. Physical characteristic of four maize hybrids.

\begin{tabular}{|c|c|c|c|c|}
\hline \multirow{2}{*}{ Physical Characteristic } & \multicolumn{4}{|c|}{ Hybrids } \\
\hline & 2B587 & A2555 & 30F98 & Somma \\
\hline $\mathrm{A}\left(10^{-2} \mathrm{~m}\right)$ & $1.30 \pm 0.06^{\mathrm{A}}$ & $1.22 \pm 0.09^{\mathrm{A}}$ & $1.29 \pm 0.07^{\mathrm{A}}$ & $1.15 \pm 0.08^{A}$ \\
\hline $\mathrm{B}\left(10^{-2} \mathrm{~m}\right)$ & $0.84 \pm 0.07^{\mathrm{A}}$ & $0.79 \pm 0.07^{\mathrm{A}}$ & $0.85 \pm 0.07^{\mathrm{A}}$ & $0.81 \pm 0.07^{\mathrm{A}}$ \\
\hline $\mathrm{C}\left(10^{-2} \mathrm{~m}\right)$ & $0.40 \pm 0.04^{\mathrm{A}}$ & $0.42 \pm 0.07^{\mathrm{A}}$ & $0.41 \pm 0.04^{\mathrm{A}}$ & $0.44 \pm 0.04^{A}$ \\
\hline Floating grains (\%) & $24.67 \pm 0.13^{A}$ & $2.33 \pm 0.03^{C}$ & $13.50 \pm 0.11^{\mathrm{B}}$ & $3.50 \pm 0.04^{C}$ \\
\hline $\begin{array}{l}\text { Volumetric mass } \\
\qquad\left(\mathrm{kg} \mathrm{L}^{-1}\right)\end{array}$ & $0.818 \pm 0.007^{\mathrm{C}}$ & $0.833 \pm 0.006^{\mathrm{B}}$ & $0.814 \pm 0.007^{\mathrm{C}}$ & $0.850 \pm 0.005^{\mathrm{A}}$ \\
\hline Mass of 100 grains $(\mathrm{kg})$ & $0.035 \pm 0.008^{\mathrm{B}}$ & $0.033 \pm 0.002^{\mathrm{C}}$ & $0.037 \pm 0.003^{A}$ & $0.035 \pm 0.005^{\mathrm{B}}$ \\
\hline
\end{tabular}

The four hybrids did not present statistical differences among their dimensions (A, B, and C), despite their distinct appearances. The Somma hybrid, which has a more vitreous appearance, showed the greatest volumetric mass. For industries, this feature indicates higher solid content (higher yield) and lower susceptibility to breakage (lower losses during harvest, transport, and processing). However, according to the test of floating grains, Somma was not the only hybrid with greater density, which is related to hardness. Both A2555, which has an intermediate appearance and Somma showed the same value of floating grains. This indicates that the semi-dent kernel appearance and lower volumetric mass are not always related to a lower density grain. The volumetric weight is a combination of grain density and the way grains are arranged in the container, while the method of floating grains provides an idea of the relationship between hard and soft endosperms (DUARTE et al., 2008).

According to Table 2, the 2B587 hybrid, which has a dent appearance, presented the highest protein content $(9.06 \%)$, while Somma, that is more vitreous, presented the lowest $(8.21 \%)$. The A2555 hybrid showed higher lipid content when compared with 2B587 and 30F98; Somma was intermediate. This was corroborated by DUARTE et al. (2008), who found more oil in A2555 than in 30F98. The highest protein percentage was observed in 2 B587 during the starch-protein separation stage (starch tables), when some protein decantation occurred along with starch, hampering its washing. This result is in agreement with the protein content obtained by the centesimal composition analysis of that hybrid (Table 2).

TABLE 2. Centesimal composition of four maize hybrids.

\begin{tabular}{ccccc}
\hline \multirow{2}{*}{ Composition (\%) } & \multicolumn{4}{c}{ Hybrids } \\
\cline { 2 - 5 } & 2B587 & A2555 & $30 \mathrm{F98}$ & Somma \\
\hline Water content & $10.80 \pm 0.27^{\mathrm{BC}}$ & $10.61 \pm 0.29^{\mathrm{C}}$ & $11.86 \pm 0.65^{\mathrm{AB}}$ & $12.20 \pm 0.32^{\mathrm{A}}$ \\
Carbohydrates & $74.41 \pm 1.53^{\mathrm{A}}$ & $73.38 \pm 1.57^{\mathrm{A}}$ & $73.50 \pm 2.21^{\mathrm{A}}$ & $74.38 \pm 0.75^{\mathrm{A}}$ \\
Proteins & $9.06 \pm 0.08^{\mathrm{A}}$ & $8.71 \pm 0.18^{\mathrm{B}}$ & $8.67 \pm 0.11^{\mathrm{B}}$ & $8.21 \pm 0.14^{\mathrm{C}}$ \\
Lipids & $3.23 \pm 0.12^{\mathrm{B}}$ & $4.77 \pm 0.29^{\mathrm{A}}$ & $3.00 \pm 0.94^{\mathrm{B}}$ & $3.77 \pm 0.11^{\mathrm{AB}}$ \\
Ashes & $1.26 \pm 0.05^{\mathrm{A}}$ & $1.14 \pm 0.02^{\mathrm{B}}$ & $1.07 \pm 0.02^{\mathrm{B}}$ & $1.08 \pm 0.02^{\mathrm{B}}$ \\
Fibers & $1.25 \pm 1.01^{\mathrm{A}}$ & $1.40 \pm 0.79^{\mathrm{A}}$ & $1.89 \pm 0.49^{\mathrm{A}}$ & $1.36 \pm 0.16^{\mathrm{A}}$ \\
\hline${ }_{\mathrm{A}, \mathrm{B}, \mathrm{C}}$ Means followed by the same letter in the row do not differ from each other by Tukey test $(\mathrm{P}<0.05)$. &
\end{tabular}

\section{Hybrid wet milling}

Table 3 shows wet milling yields of the four hybrids. 
TABLE 3. Yields of the byproducts recovered from the wet millings of four maize hybrids.

\begin{tabular}{|c|c|c|c|c|c|c|c|c|}
\hline \multirow{2}{*}{\multicolumn{2}{|c|}{$\begin{array}{c}\text { Lactic } \\
\text { Hybrid Acid } \\
(\%)\end{array}$}} & \multicolumn{4}{|c|}{$\begin{array}{c}\text { Byproduct yields } \\
(\%)\end{array}$} & \multicolumn{2}{|c|}{$\begin{array}{l}\text { Solids in the processing water } \\
(\%)\end{array}$} & \multirow[t]{2}{*}{ Total Yield (\%) } \\
\hline & & Germ & Fiber & Starch & Protein & Steeping & Filtration & \\
\hline \multirow{2}{*}{ 2B587 } & 0.55 & $7.27^{\mathrm{C}}$ & $12.12^{\mathrm{A}}$ & $61.15^{A}$ & $10.46^{A}$ & $4.84^{\mathrm{A}}$ & $2.70^{\mathrm{A}}$ & $98.74^{\mathrm{A}}$ \\
\hline & 1.00 & $7.25^{\mathrm{C}}$ & $12.00^{\mathrm{A}}$ & $61.70^{\mathrm{A}}$ & $9.76^{\mathrm{A}}$ & $5.67^{\mathrm{A}}$ & $2.59^{\mathrm{A}}$ & $98.97^{\mathrm{A}}$ \\
\hline \multirow{2}{*}{ 30F98 } & 0.55 & $8.26^{\mathrm{B}}$ & $10.11^{\mathrm{A}}$ & $61.90^{\mathrm{A}}$ & $10.71^{\mathrm{A}}$ & $5.24^{\mathrm{A}}$ & $1.85^{\mathrm{A}}$ & $98.07^{\mathrm{A}}$ \\
\hline & 1.00 & $7.91^{\mathrm{BC}}$ & $9.87^{\mathrm{A}}$ & $62.80^{\mathrm{A}}$ & $9.26^{\mathrm{A}}$ & $6.06^{\mathrm{A}}$ & $2.21^{\mathrm{A}}$ & $98.11^{\mathrm{A}}$ \\
\hline \multirow{2}{*}{ Somma } & 0.55 & $7.79^{\mathrm{BC}}$ & $11.98^{\mathrm{A}}$ & $62.79^{A}$ & $9.75^{A}$ & $5.04^{\mathrm{A}}$ & $2.40^{\mathrm{A}}$ & $99.75^{A}$ \\
\hline & 1.00 & $7.77^{\mathrm{BC}}$ & $9.80^{\mathrm{A}}$ & $63.82^{\mathrm{A}}$ & $10.61^{\mathrm{A}}$ & $5.46^{\mathrm{A}}$ & $2.33^{A}$ & $99.79^{\mathrm{A}}$ \\
\hline \multirow[b]{2}{*}{ A2555 } & 0.55 & $8.59^{A}$ & $11.94^{\mathrm{A}}$ & $61.76^{A}$ & $10.58^{A}$ & $4.79^{A}$ & $2.20^{\mathrm{A}}$ & $99.86^{\mathrm{A}}$ \\
\hline & 1.00 & $8.39^{\mathrm{AB}}$ & $9.46^{\mathrm{A}}$ & $62.98^{\mathrm{A}}$ & $10.24^{\mathrm{A}}$ & $6.23^{A}$ & $2.58^{\mathrm{A}}$ & $99.88^{\mathrm{A}}$ \\
\hline
\end{tabular}

A, B, C Means followed by the same letter in the row do not differ from each other by Tukey test $(\mathrm{P}<0.05)$.

It is observed in Table 3 that the A2555 hybrid provided the best germ yields (mean of 8.49\%). The larger germ size of this hybrid enabled its recovery, so germs were bigger, entire, and with minor physical damages due to the first milling. Such minor physical damages indicate that the steeping stage was adequate for this hybrid, as it was sufficient to soften the grain and provide better separation of components.

The 2B587 hybrid presented smaller germs that broke easily during all milling tests, what hindered their recovery and provided low yields (mean of $7.26 \%$ ). This recovery difficulty cannot be related to the lowest lipid content $(3.23 \pm 0.12 \%)$ of its centesimal composition, when compared to the other hybrids (Table 2), as the 30F98 presents similar lipid content (3.00 $\pm 0.94 \%$ ), but its germ recovery was not hampered because of this. Therefore, the greater recovery difficulty and breakage of 2B587 germs may be associated with other characteristics, such as lower diffusion of the steeping water into the grain. Thus, the grain was not soft enough to avoid germ damage. Among the factors that may have hindered diffusion, there are higher percentage of fibers and ashes as well as high protein content, which is responsible for greater endosperm compression.

Fiber yields did not differ among hybrids. However, great damage and difficult recovery of 2B587 germs probably promoted the recovery of small germ pieces along with the fiber fraction (finer sieve), what may have influenced its fiber yield. According to LOPES FILHO (1999), when steeping is not sufficient, regarding time and amounts of $\mathrm{SO}_{2}$ and lactic acid, the fiber fraction is greater, as part of the starch and, even, of the protein moiety, remains aggregated to it. Thus, the greater the breakage of protein networks, which main responsible is $\mathrm{SO}_{2}$ combined with major ease of fiber washing, where the lactic acid has an important role, the lower the "contamination" of the fiber fraction; therefore, fiber fraction final yield will be lower, what is desired for maize starch production. It is observed in Table 3 that, although there was no statistical difference for fiber yield, 2B587 values were higher than the other hybrids. This was also verified in practice because of greater fiber washing difficulty of this hybrid. For every milling, this hybrid provided fibers with gelatinous aspect due, mainly, to starch presence.

Protein yields, presented in Table 3 (mean of 10.17\%) are consistent with other studies (SINGH \& ECKHOFF, 1996; MANZONI, 2000) and were not statistically different from each other. However, percentages of the proteins recovered from milling are higher than protein percentages in hybrid compositions, as shown in Table 2, i.e., grains had increasing yields due to contamination by other fractions. Some factors may have influenced this increase, such as "contamination" by starch due to some process failure, like deregulation of the channel inclination or pump flow. Considering that "contamination" was proportional for all hybrids, the 2B587 should have shown greater recovery of the "contaminated" protein fraction, since it had higher protein content in its composition, as presented in Table $2(9.06 \pm 0.08 \%)$. However, its recovery was similar to the other hybrids, indicating that, despite having higher protein content in its composition, it provided lower protein yields, possibly for having been impaired by softening lack due to 
penetration difficulty of the steeping solution. For not being properly softened, grain germs were broken during first milling, releasing high oil content in the solution. This released oil is less dense than water, what facilitates protein decantation along with starch in the channel, hampering its recovery. FOX et al. (1992) observed that grains with higher protein percentage also showed high content of residual protein in the obtained starch due to greater difficulty in the starch-protein separation stage. This difficulty of protein outflow on the starch table was observed in practice, since 2B587 proteins decanted along the entire channel, hindering starch washing and impairing its yield.

Starch yields were not statistically different among hybrids and are consistent with other studies in the literature (SINGH \& ECKHOFF, 1996; MANZONI, 2000) (mean of 62.36\%). Despite the absence of statistical difference, we verified that the 2B587 hybrid tended to present lower yields, suggesting that diffusion of the steeping water into grains was difficult, resulting in lower starch yields due to losses in other fractions, especially in the fiber one.

As observed in this study, with only the exception of the byproduct germ, chemical and physical characteristics did not affect yields of other byproducts from the maize hybrids under the established milling conditions. However, the tendency of some influences was verified, which could be explored and more clearly analyzed in other studies with different lactic acid levels.

\section{Lactic acid influence}

Higher lactic acid concentration favors penetration of the steeping solution into grains, increasing efficiency of $\mathrm{SO}_{2}$ performance on the rupture of protein chains. The component separation is facilitated, improving by product recovery. Values in Table 3 indicate, on average, a tendency for higher yields from the use of $1.00 \%$ lactic acid concentration. However, results were not statistically different between the two levels. A total yield of $98-99 \%$ is common in the wet milling procedure and a recovery lower than 97\%, according to DU et al. (1996), is not acceptable. Results of this study fall within the expected.

There was also an increase in the percentage of soluble solids in the steeping solution with 1.00\% lactic acid. WANG (1994) and LOPES FILHO et al. (1997) also reported higher amounts of soluble solids. This occurs due to increased lactic acid activity, which promotes higher porosity in the grain pericarp (ROUSHDI et al., 1981), facilitating diffusion of soluble solids into the steeping solution. Moreover, higher ease of component recovery, especially of germs, was observed in practice for all millings with $1.00 \%$ lactic acid.

Despite the absence of statistical difference, fibers tended to present lower yield according to the increase in lactic acid, what means that part of the fiber recovered during milling with $0.55 \%$ lactic acid, may be the residual starch. As grain hydration was more efficient, a better component separation occurred and starch was more easily recovered (LOPES FILHO, 1999).

According to the statistical analysis performed for the studied hybrids, there is no advantage in using $1.00 \%$ lactic acid in comparison with the $0.55 \%$ concentration. Higher levels may be tested to confirm these results.

\section{CONCLUSIONS}

Density and chemical composition of grains must not be separately considered to predict yields of byproducts from wet milling.

The increase in lactic acid concentration from 0.55 to $1.00 \%$ in the steeping water does not influence yields of byproducts of the studied hybrids. However, it facilitates component recovery, especially of germs.

\section{ACKNOWLEDGMENTS}

To FAPESP, for supporting this research (06/01775-2). 


\section{REFERENCES}

AACC - American Association of Cereal Chemists. Approved methods. $9^{\text {th }}$ ed. St. Paul, 1995. v. 2. BANZATTO, D. A.; KRONKA, S. D. Experimentação agrícola. 3.ed. Jaboticabal: FUNEP, 1995. DU, L.; LI, B.; LOPES FILHO, J. F.; DANIELS, C. R.; ECKHOFF, S. R. Effect of selected organic and inorganic acids on corn wet milling yields. Cereal Chemistry, Saint Paul, v. 73, n. 1, p. 96-98, 1996.

DUARTE, A.P.; CARVALHO, C.R.L.; CAVICHIOLI, J.C. Densidade, teor de óleo e produtividade de grãos em híbridos de milho. Bragantia, Campinas, v.67, n.3, p.563-571, 2008.

ECKHOFF, S. R.; TSO, C.C. Wet milling of corn using gaseous $\mathrm{SO}_{2}$ addition before steeping and the effect of lactic on steeping. Cereal Chemistry, Saint Paul, v. 68, n. 3, p.248-251, 1991.

FOX, S. R.; JOHNSON, L. A.; HURBURGH, C. R.; DORSEY-REDDING, C.; BAILEY, T. B. Relations of grain proximate composition and physical properties to wet milling characteristics of maize. Cereal Chemistry, Saint Paul, v. 69, n. 2, p. 191-197, 1992.

HANAN, R.; PURCHWITE, M.; ROSENTRETER, E. (Ed). ASAE Standards. St. Joseph, 1985.

IAL - Instituto Adolfo Lutz. Normas Analíticas do Instituto Adolfo Lutz: métodos químicos e físicos para análises de alimentos. 3.ed. São Paulo, 1985. v.1.

LOPES FILHO, J. F. Avaliação da maceração dinâmica do milho após um curto período de hidratação e subseqüente quebra do pericarpo do grão. Ciência e Tecnologia de Alimentos, Campinas, v. 19, n. 3, p. 322-325, 1999.

LOPES FILHO, J. F.; BURIAK, P.; TUMBLESON, M.E.; ECKHOFF, S. R. Intermittent milling and dynamic steeping process for corn starch recovery. Cereal Chemistry, Saint Paul, v. 74, n.5, p.633-638, 1997.

LOPES FILHO, J. F.; RAMOS, A. P.; ROMERO, J. T. Difusividade da água, dióxido de enxofre e ácido lático em grãos de milho durante a maceração para o processo de moagem úmida. Brazilian Journal of Food Technology, Campinas, v. 9, n. 4, p. 257-263, 2006.

MANZONI, M. S. J. Influência da temperatura, níveis de dióxido de enxofre e ácido lático durante maceração dinâmica e moagem intermitente para obtenção de subprodutos do milho. $108 \mathrm{f}$. Dissertação (Mestrado em Engenharia e Ciência de Alimentos) - Universidade Estadual Paulista, São José do Rio Preto, 2000.

MERTENS, D. R. Análise da fibra e sua utilização na avaliação de alimentos e formulação de rações. In: SIMPÓSIO INTERNACIONAL DE RUMINANTES, 1992, Lavras. Anais...Lavras: SBZ/ESAL, 1992.

PEPLINSKI, A. J.; PAULSEN, M. R.; ANDERSON, R. A.; KWOLEK, W. F. Physical, chemical, and dry-milling characteristics of corn hybrids from various genotypes. Cereal Chemistry, Saint Paul, v. 66, n. 2, p. 117-120, 1989.

ROUSHDI, M.; GHALI, Y.; HASSANEAN, A. Factors improving steeping process of corn grains, part III. Conditions favoring lactic acid formation during corn stepping and its effect. Starch-Starke, Weinheim, v. 33, p.49-52, 1981.

SINGH, N.; ECKHOFF, S.R. Wet milling of corn: a review of laboratory - scale and pilot plantscale procedures. Cereal Chemistry, Saint Paul, v.73, n.6, p.659-667, 1996.

WANG, D. Effect of broken and pericarp demaged corn on water absorption and steepwater characteristics. Dissertação (Mestrado Engenharia Agrícola) - Universidade de Illinois, Illinois, 1994. 